Supporting Information

\title{
Covalent Catalysis by Cross $\beta$ Amyloid Nanotubes
}

Baishakhi Sarkhel, Ayan Chatterjee and Dibyendu Das*

Department of Chemical Sciences and Centre for Advanced Functional Materials, Indian Institute of Science Education and Research (IISER) Kolkata, Mohanpur 741246, India. 


\begin{tabular}{|l|l|l|}
\hline 1. & Materials & $\mathrm{S} 3$ \\
\hline 2. & Methods & $\mathrm{S} 3$ \\
\hline 2.1. & Synthesis & $\mathrm{S} 3$ \\
\hline 2.2. & Experimental technique & $\mathrm{S} 9$ \\
\hline 3. & Table S1: activity of various system for hydrolysis of 1 & $\mathrm{S} 14$ \\
\hline 5. & Table S2: kinetic parameters for hydrolysis for the different substrates & $\mathrm{S} 14$ \\
\hline 6. & AFM micrographs and Histogram & $\mathrm{S} 15$ \\
\hline 7. & FTIR of Im-KL & $\mathrm{S} 15$ \\
\hline 9. & TEM image of negatively-charged gold nanoparticles and bound systems & $\mathrm{S} 16$ \\
\hline 10. & CLSM images of coumarin dye without Im-KL tubes & $\mathrm{S} 16$ \\
\hline 12. & CD Spectra of Im-RL & $\mathrm{S} 17$ \\
\hline 13. & Michaelis - Menten plot for different systems & $\mathrm{S} 18$ \\
\hline 14. & TEM image of Im-EL & $\mathrm{S} 18$ \\
\hline 15. & X ray powder diffraction spectra of Im-OL & $\mathrm{S} 19$ \\
\hline 16. & CD spectra and TEM image of HFIP treated Im-KL & $\mathrm{S} 19$ \\
\hline 17. & Fluorescence study of Ar-CHO with Im-KL and Im-RL & $\mathrm{S} 20$ \\
\hline 18. & Fluorescence study of ANS and pyrene with Im-KL and Im-RL \\
\hline 19. & UV spectra for the hydrolysis of 3 & $\mathrm{S} 21$ \\
\hline 20. & Standard plot of absorbance for Ar-CHO \\
\hline 21. & Standard plot of fluorescence intensity for 2-Naphthol \\
\hline 22. & $\begin{array}{l}\text { Time dependent HPLC chromatogram and standard plots of hydrolyzed } \\
\text { products }\end{array}$ & $\mathrm{S} 22$ \\
\hline 23. & HPLC chromatogram of purified peptides & \\
\hline & & $\mathrm{S} 23$ \\
\hline
\end{tabular}




\section{Materials:}

All fluorenylmethyloxycarbonyl (Fmoc) protected amino acids, activator DIC (N,N'Diisopropylcarbodiimide), DIPEA ( $N, N$-diisopropylethylamine), piperidine, Trifluoroacetic acid (TFA), 1,1,1,3,3,3-Hexafluoro-2-propanol (HFIP), gold chloride trihydrate, sodium borohydride and trisodium citrate dehydrate were purchased from Sigma Aldrich. Oxyma was purchased from Nova Biochem. 4-Nitrophenol was purchased from SRL. Imidazole acetic acid and valeric acid were purchased from Alfa Aesar. Levulinic acid, 6-Hydroxy Naphthaldehyde, HEPES (4(2-hydroxyethyl)-1-piperazineethanesulfonic acid), 2-Naphthol, and p-Nitro phenyl acetate (PNPA) were purchased from TCI, Japan. All solvents and Fmoc-Rink amide MBHA Resin were purchased from Merck. Milli-Q water was used throughout the experiments.

\section{Methods:}

\subsection{Synthesis:}

\section{Synthetic procedure of peptides:}

All peptides (ImKLVFFAL, ImRLVFFAL, ImOLVFFAL, ImELVFFAL) were synthesized using Aapptec peptide synthesizer. Fmoc-Rink Amide MBHA Resin (loading $0.52 \mathrm{mmol} / \mathrm{g}$ ) was swollen using dimethylformamide (DMF) for 15 minutes followed by Fmoc deprotection with $20 \%$ piperidine in DMF. Each Fmoc-amino acid coupling step was performed using DIC as activator and oxyma solution in DMF. Finally, imidazoleacetic acid was coupled manually to the N-terminal of heptapeptides using HBTU as coupling reagent and HOBT. Resin was washed with DMF and dichloromethane (DCM) respectively and allowed to air dry. Peptides are cleaved from resin using Trifluoroacetic acid (TFA)/Triethylsilane (5:0.1 v/v) at room temperature for 2 hours. The cleaved peptide-TFA solution was filtered and TFA was removed using high vacuum, it was precipitated by dropwise addition to ice-cold diethyl ether. Precipitated product was centrifuged at $8000 \mathrm{rpm}$ for $15 \mathrm{~min}$ at $4{ }^{\circ} \mathrm{C}$ in Eppendorf centrifuge $5804 \mathrm{R}$ and further the pellet was washed 3 times with cold diethyl ether. The crude peptides were purified on a preparative Waters HPLC system with Atlantis T3 C18 preparative reverse phase column, using a linear gradient of water containing $0.1 \%$ TFA and acetonitrile containing 0.1\% TFA (Figure S18-21). Molecular weight was confirmed by Bruker Mass Spec Q-tof systems. 
ImKLVFFAL-NH $\mathrm{NH}_{2} \quad(\mathrm{Im}-\mathrm{KL}) \quad\left(\mathrm{C}_{49} \mathrm{H}_{73} \mathrm{~N}_{11} \mathrm{O}_{8}\right) \quad(\mathrm{m} / \mathrm{z})$ calculated for $\left[\mathrm{M}+\mathrm{H}^{+}\right]$: 944.5677; found: 944.5866

ImRLVFFAL- $\mathrm{NH}_{2} \quad(\mathrm{Im}-\mathbf{R L}) \quad\left(\mathrm{C}_{49} \mathrm{H}_{73} \mathrm{~N}_{13} \mathrm{O}_{8}\right) \quad(\mathrm{m} / \mathrm{z})$ calculated for $\left[\mathrm{M}+\mathrm{H}^{+}\right]$: 972.5739; found: 972.5816

ImOLVFFAL-NH $\mathrm{NH}_{2}$ (Im-OL) $\left(\mathrm{C}_{48} \mathrm{H}_{71} \mathrm{~N}_{11} \mathrm{O}_{8}\right) \quad(\mathrm{m} / \mathrm{z})$ calculated for $\left[\mathrm{M}+\mathrm{H}^{+}\right]$: 930.5521; found: 930.6575

ImELVFFAL-NH $\mathrm{NH}_{2}$ (Im-EL) $\left(\mathrm{C}_{48} \mathrm{H}_{68} \mathrm{~N}_{10} \mathrm{O}_{10}\right) \quad(\mathrm{m} / \mathrm{z})$ calculated for [M+Na+]: 967.4920; found: 967.4797

\section{Synthesis of Negatively Charged gold nanoparticle}

This involves the preparation of a $20 \mathrm{~mL}$ aqueous solution containing $2.5 \times 10^{-4} \mathrm{M} \mathrm{HAuCl}_{4}$, and $2.5 \times 10^{-4} \mathrm{M}$ trisodium citrate. To this solution $600 \mu \mathrm{L}$ of ice cold $0.1 \mathrm{M} \mathrm{NaBH}_{4}$ was added with constant stirring. The solution immediately turned orange-red, indicating the formation of gold nanoparticles with a localized surface plasmon resonance (SPR) transmission at $507 \mathrm{~nm}$. Average particle size of $7 \pm 1 \mathrm{~nm}$ was measured from transmission electron microscopy (TEM).

\section{Synthesis of substrates}

\section{Synthesis of p-nitrophenyl 4-oxopentanoate (1):}

Levulinic acid (4 g), 4-nitrophenol (4NP) and N, N'-dicyclohexylcarbodiimide (DCC) were dissolved in dry ethyl acetate in a round bottom flask under nitrogen atmosphere. The mixture was stirred for $20 \mathrm{~h}$. Solids were filtered off and washed with water and saturated aq. $\mathrm{NaHCO}_{3}$. The aqueous phase was extracted with ethyl acetate. Combined organic layers were washed with brine and dried over $\mathrm{Na}_{2} \mathrm{SO}_{4}$. The final crude product was obtained by removing ethyl acetate under vacuum, then it was purified by column chromatography to get $\mathbf{1}$.

${ }^{1} \mathrm{H}$ NMR (400 MHz, CDCl $)$ ) $(\mathrm{ppm})$ 8.25(d, 2H), 7.26 (d, 2H), 2.85 (m, 4H), $2.22(\mathrm{~s}, 3 \mathrm{H})$.

${ }^{13} \mathrm{C}$ NMR $\left(100 \mathrm{MHz}, \mathrm{CDCl}_{3}\right) \delta(\mathrm{ppm}) 206.11,170.59,155.40,145.36,125.17,122.41,37.81$, 29.73, 28.12.

ESI-MS $1\left(\mathrm{C}_{11} \mathrm{H}_{11} \mathrm{NO}_{5}\right)(\mathrm{m} / \mathrm{z})$ calculated for $\left[\mathrm{M}+\mathrm{Na}^{+}\right]$: 260.0535; found: 260.0548 
数

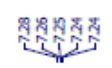

I

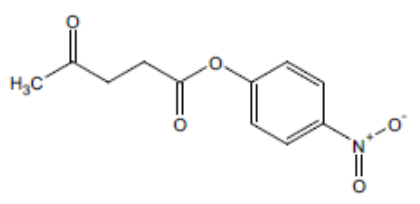

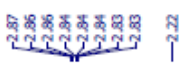

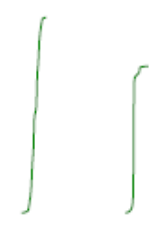

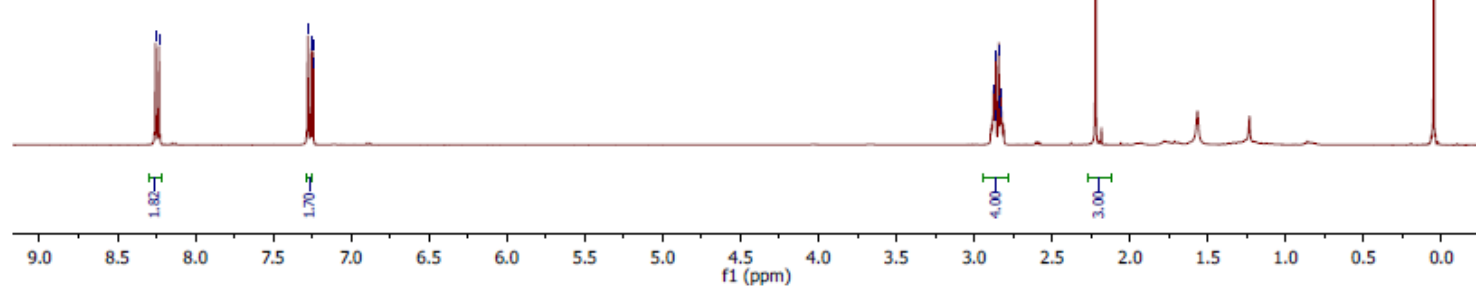

${ }^{1} \mathrm{H}$ NMR spectrum of $\mathbf{1}$

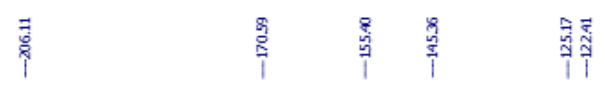

离㩆
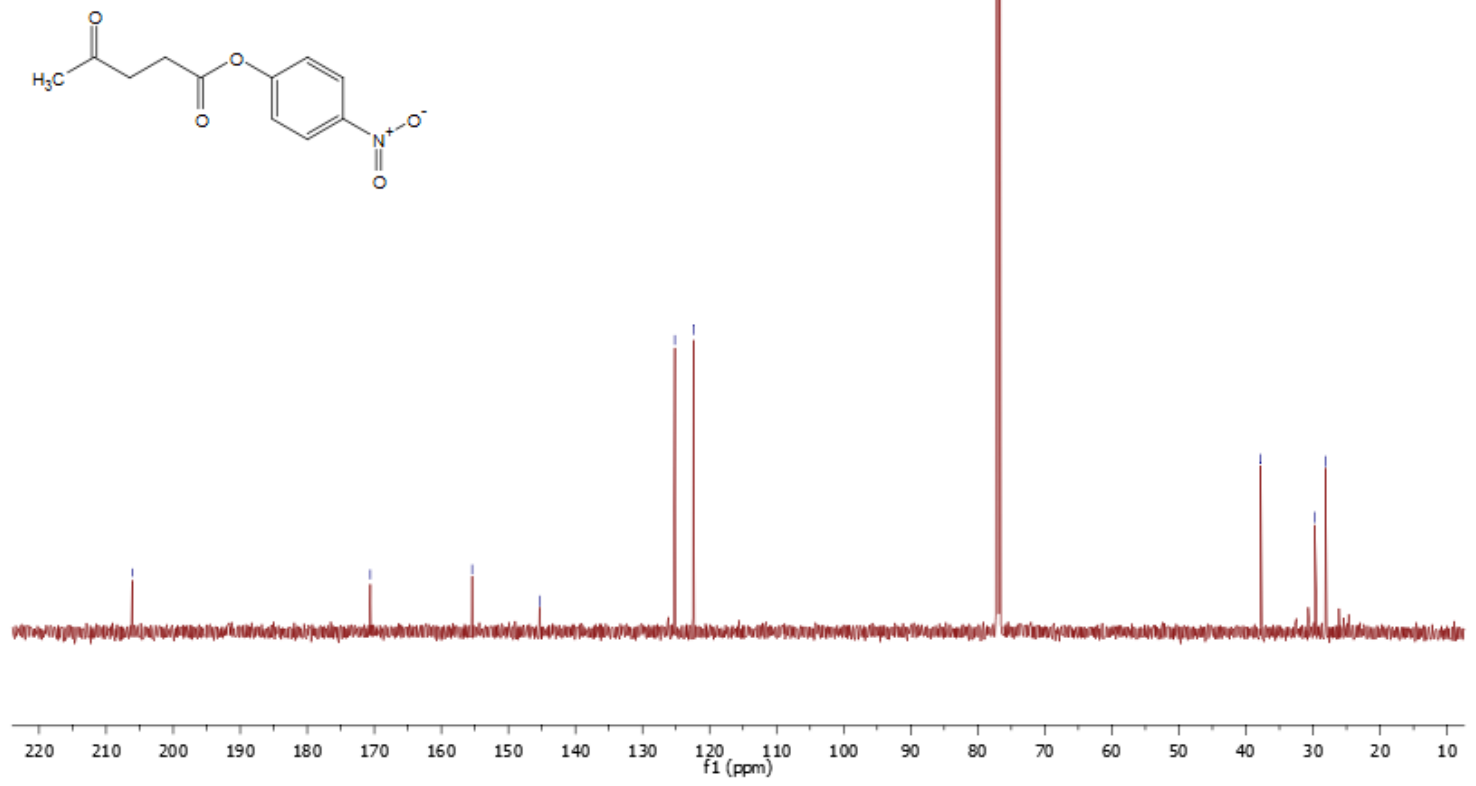

${ }^{13} \mathrm{C}$ NMR spectrum of 1

SF 


\section{Synthesis of p-nitrophenyl pentanoate (2):}

2 was synthesized following the above protocol using DCC as coupling reagent.

${ }^{1} \mathrm{H}$ NMR $\left(400 \mathrm{MHz}, \mathrm{CDCl}_{3}\right) \delta(\mathrm{ppm}) 8.30(\mathrm{~d}, 2 \mathrm{H}), 7.30(\mathrm{~d}, 2 \mathrm{H}), 2.63(\mathrm{t}, 2 \mathrm{H}), 1.78(\mathrm{~m}, 2 \mathrm{H}), 1.48$ $(\mathrm{m}, 2 \mathrm{H}), 1.01(\mathrm{t}, 3 \mathrm{H})$.

${ }^{13} \mathrm{C}$ NMR $\left(100 \mathrm{MHz}, \mathrm{CDCl}_{3}\right) \delta$ (ppm) 171.39, 155.60, 145.28, 125.24, 122.51, 34.09, 26.84, $22.25,13.76$.

ESI-MS $2\left(\mathrm{C}_{11} \mathrm{H}_{13} \mathrm{NO}_{4}\right)(\mathrm{m} / \mathrm{z})$ calculated for $\left[\mathrm{M}+\mathrm{Na}^{+}\right]: 246.0742$, found 246.0686
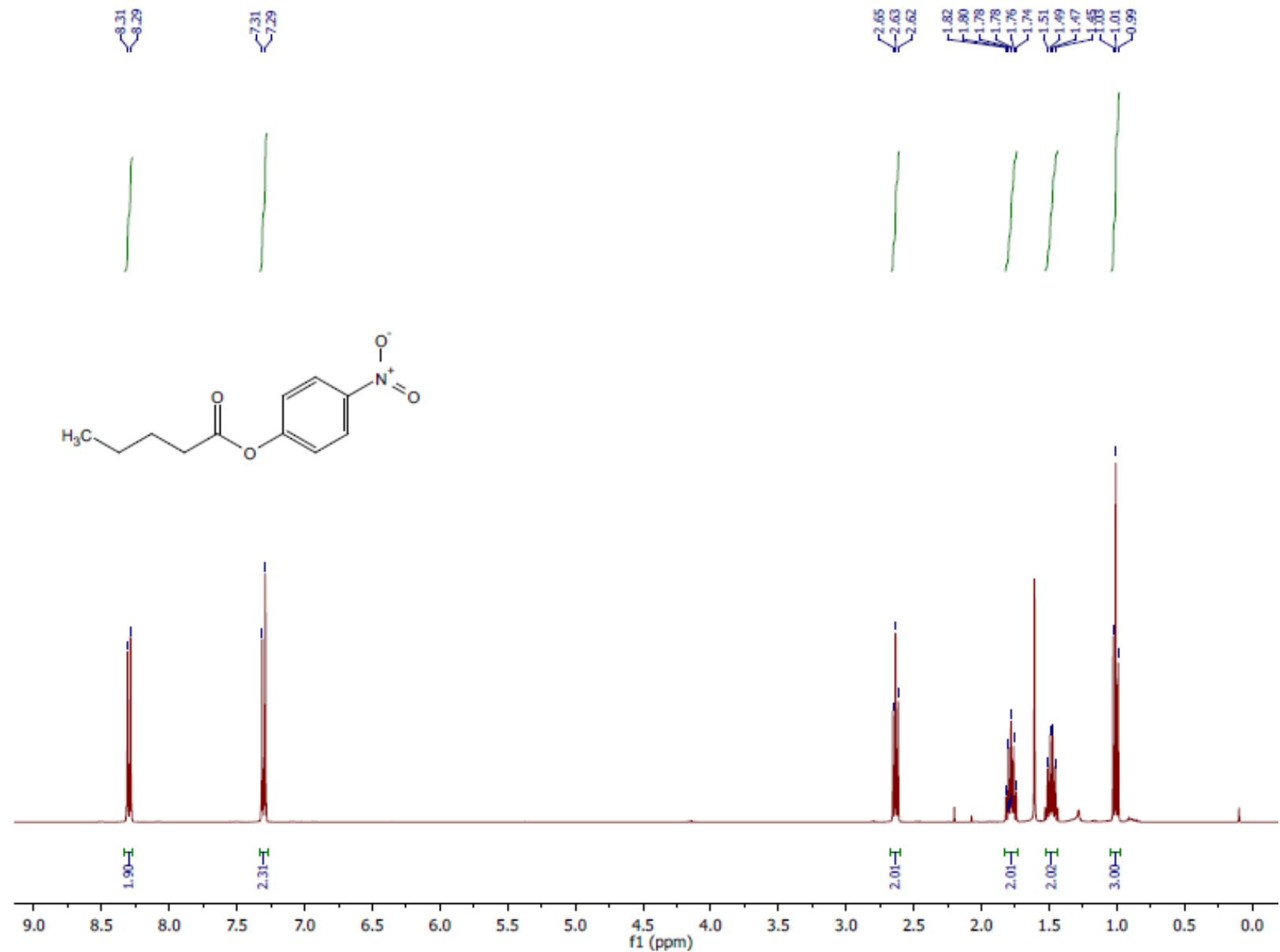

${ }^{1} \mathrm{H}$ NMR spectrum of 2 


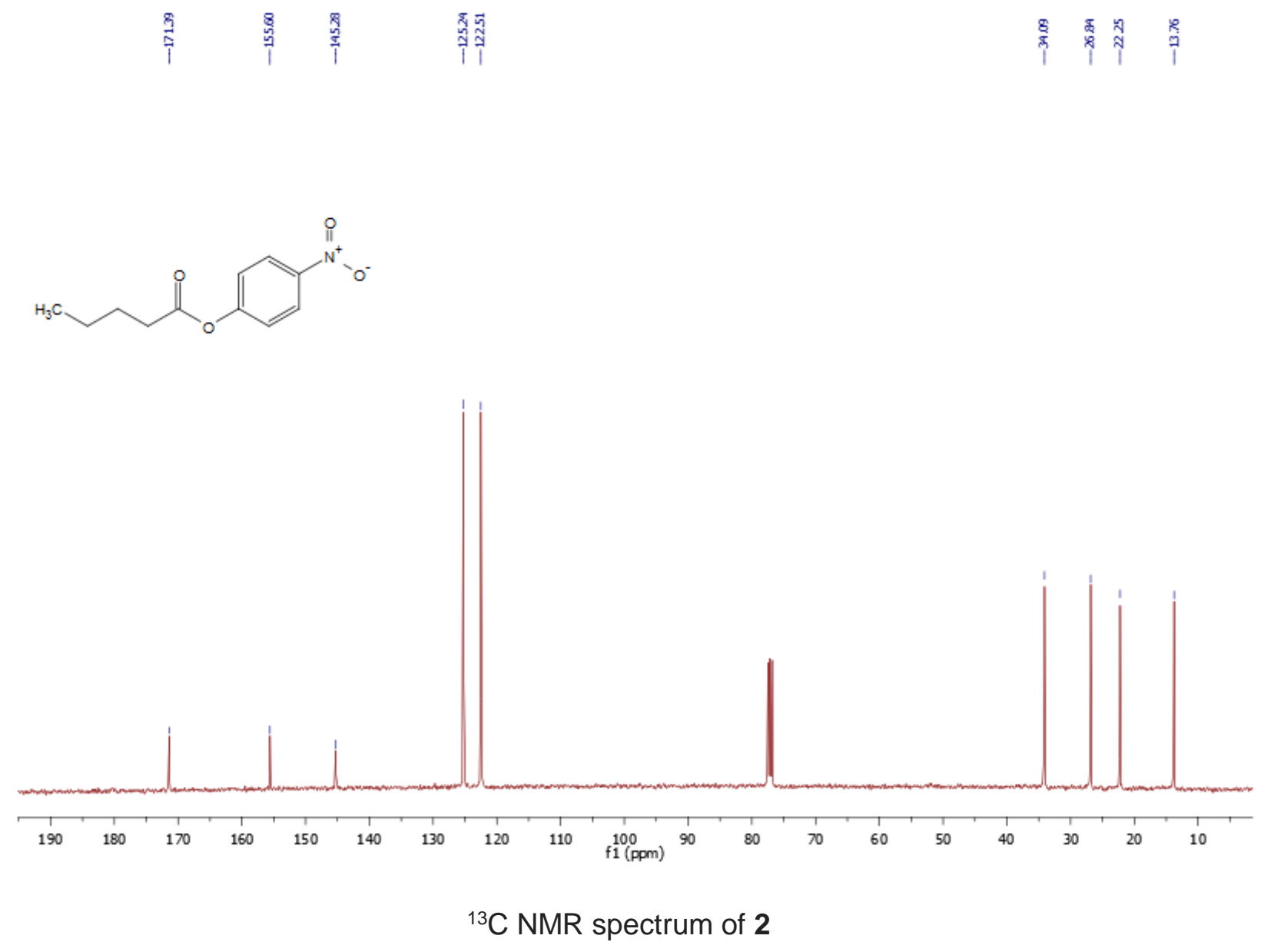

\section{Synthesis of 6-formyl napthalene-2-yl acetate (3) ${ }^{1}$ :}

To a solution of 6-hydroxy naphthaldehyde in DCM, pyridine and excess acetic anhydride were added. This reaction mixture was stirred for $4 \mathrm{~h}$ at $45^{\circ} \mathrm{C}$. The final product was obtained by removing DCM under vacuum. The obtained product was confirmed from ${ }^{1} \mathrm{H}$ NMR.

${ }^{1} \mathrm{H}$ NMR $\left(400 \mathrm{MHz}, \mathrm{CDCl}_{3}\right) \delta(\mathrm{ppm}) 10.14(\mathrm{~s}, 1 \mathrm{H}), 8.33(\mathrm{~s}, 1 \mathrm{H}), 8.02(\mathrm{~d}, 1 \mathrm{H}), 7.96(\mathrm{dd}, 1 \mathrm{H})$, $7.89(\mathrm{~d}, 1 \mathrm{H}), 7.63(\mathrm{~d}, 1 \mathrm{H}), 7.34(\mathrm{~d}, 1 \mathrm{H}), 2.36(\mathrm{~s}, 3 \mathrm{H})$.

ESI-MS $3\left(\mathrm{C}_{13} \mathrm{H}_{10} \mathrm{O}_{3}\right)(\mathrm{m} / \mathrm{z})$ calculated for $\left[\mathrm{M}+\mathrm{H}^{+}\right]$: 215.0663, found 215.0744 


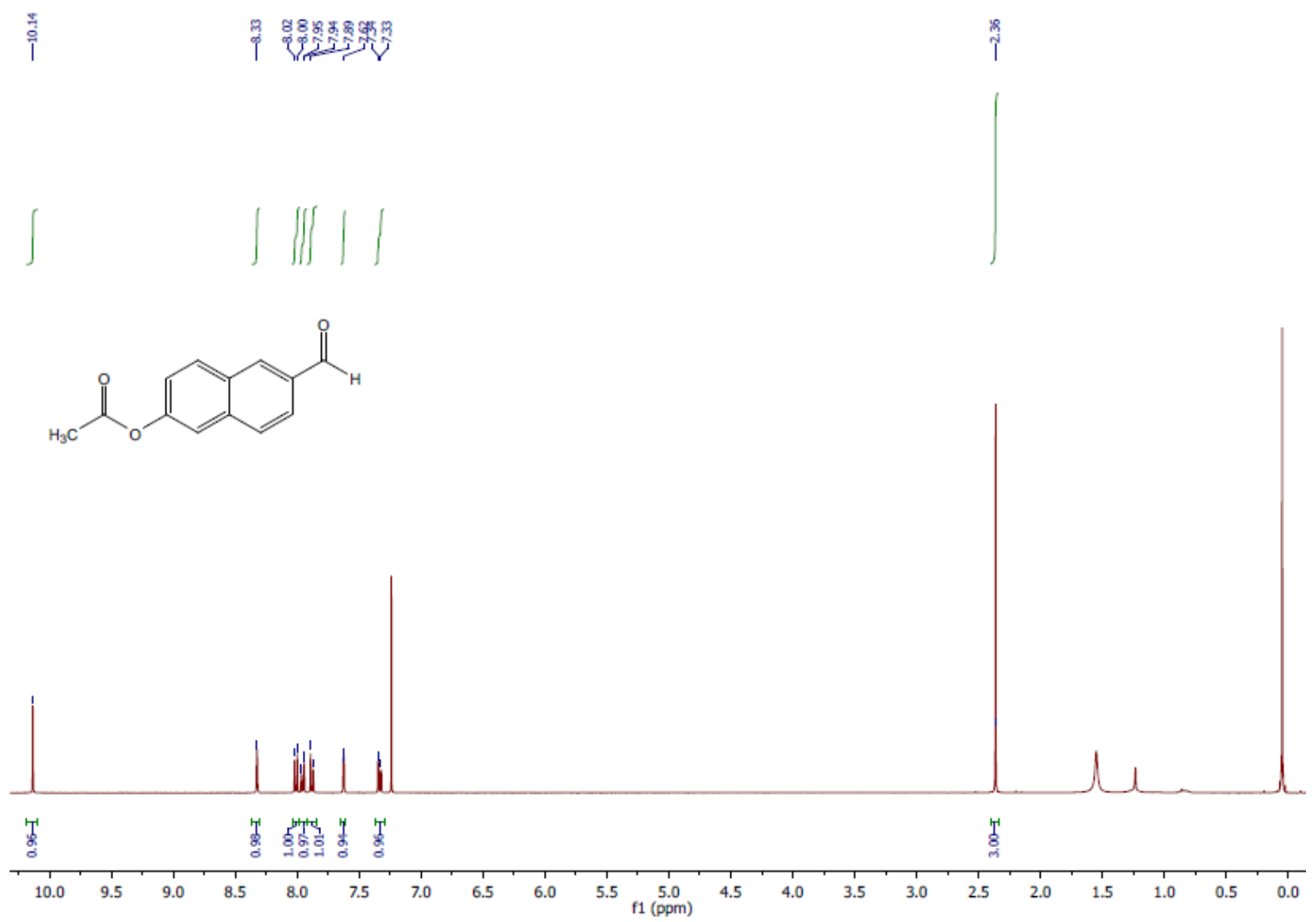

${ }^{1} \mathrm{H}$ NMR spectrum of $\mathbf{3}$

\section{Synthesis of naphthalene-2-yl-acetate (4) ${ }^{2}$ :}

To a solution of 2-naphthol in DCM, pyridine and excess acetic anhydride were added. This reaction mixture was stirred for $4 \mathrm{~h}$ at $45^{\circ} \mathrm{C}$. The final product was obtained by removing DCM under vacuum. The obtained product was confirmed from ${ }^{1} \mathrm{H}$ NMR.

${ }^{1} \mathrm{H}$ NMR $\left(400 \mathrm{MHz}, \mathrm{CDCl}_{3}\right) \delta(\mathrm{ppm}) 7.8(\mathrm{~m}, 3 \mathrm{H}), 7.56(\mathrm{~d}, 1 \mathrm{H}), 7.45(\mathrm{~m}, 2 \mathrm{H}), 7.23(\mathrm{dd}, 1 \mathrm{H}), 2.36$ $(\mathrm{s}, 3 \mathrm{H})$.

ESI-MS $4\left(\mathrm{C}_{12} \mathrm{H}_{10} \mathrm{O}_{2}\right)(\mathrm{m} / \mathrm{z})$ calculated for $\left[\mathrm{M}+\mathrm{Na}^{+}\right]$: 209.0578, found 209.0481 


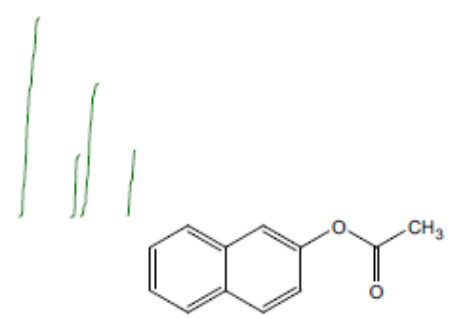

$$
\text { i }
$$

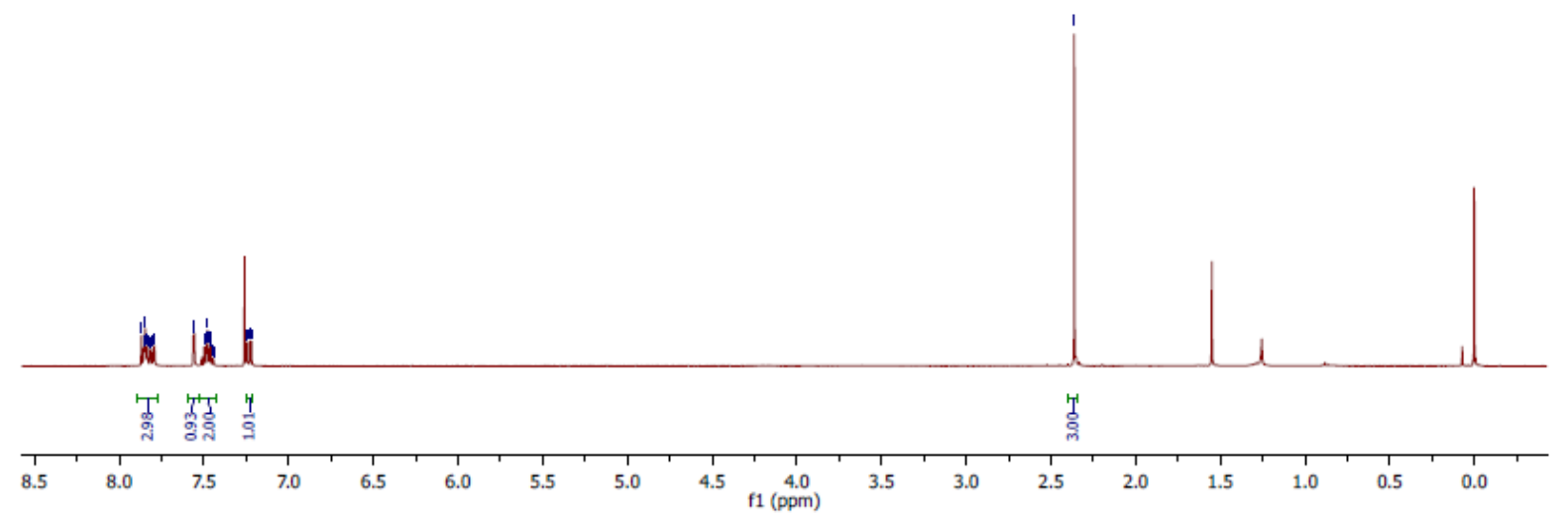

${ }^{1} \mathrm{H}$ NMR spectrum of 4

\subsection{Experimental technique}

\subsubsection{Peptide assembly}

In order to eliminate any preformed assembly that may formed during purification, purified peptide was treated with HFIP and dried with nitrogen flow. After drying, peptide film was dissolved in $40 \%$ acetonitrile-water containing $0.1 \%$ Trifluoroacetic acid. ${ }^{3-5}$ Then $\mathrm{pH}$ was adjusted to 8 by drop-wise addition of $\mathrm{NaOH}$. The homogeneous solution was kept for a month before using.

\subsubsection{Redispersion technique}

$1 \mathrm{~mL}$ of assembled peptide sample $(2.5 \mathrm{mM})$ was taken in $1.5 \mathrm{~mL}$ microcentrifuge tube and was centrifuged for $15 \mathrm{~min}$ at 12,000 rpm (rotor F45-30-11) at $4{ }^{\circ} \mathrm{C}$ temperature in Eppendorf centrifuge $5804 \mathrm{R}$. The Pellet obtained after discarding the supernatant was redispersed in water. 


\subsubsection{Transmission electron microscopy Imaging (TEM)}

Peptide assemblies were diluted to $300 \mu \mathrm{M}$ using $40 \%$ acetonitrile-water followed by the adsorption on a TEM grid for $1 \mathrm{~min}$. Excess peptide solution was wicked off with the filter paper. It was followed by the addition of $10 \mu \mathrm{l}$ of $1 \%(\mathrm{w} / \mathrm{v})$ Uranyl acetate and incubated for 1 min. Samples were then kept in a desiccator under vacuum for 25 min. TEM micrographs were recorded with a JEOL JEM 2100 with a Tungsten filament at an accelerating voltage of 200 $\mathrm{kV}$.

\subsubsection{Gold Nanomaterials binding studies}

For gold nanoparticle binding studies, $200 \mu \mathrm{L}$ of gold colloid (both positively charged and negatively charged AuNP, $0.24 \mathrm{mM}$ ) were separately added to $5 \mu \mathrm{L}$ of the aqueous dispersions of nanotubes of Im-KL. The mixture was kept for incubation for ca. $2 \mathrm{~h}$ at room temperature until a purple red precipitate was formed. The mixture was centrifuged and the pellet was redispersed in water. $10 \mu \mathrm{L}$ of this solution was carefully drop casted on TEM grids and aged for 2 min before wicking off the excess solvent with filter paper.

\subsubsection{Atomic Force Microscope (AFM)}

The samples were air dried and scanned under ambient conditions using Bruker Multimode 8 scanning probe microscope operated in tapping mode with Nanoscope $\mathrm{V}$ controller and a $\mathrm{J}$ scanner.

\subsubsection{Circular Dichroism}

CD spectra were recorded using a JASCO J-810 circular dichroism spectrometer fitted with a Peltier temperature controller to maintain the temperature at $25^{\circ} \mathrm{C} .400 \mu \mathrm{L}$ of the peptide samples $(2.5 \mathrm{mM})$ were placed into a quartz cuvette with $1 \mathrm{~mm}$ path length. Each spectrum was obtained by scanning wavelength from $600 \mathrm{~nm}$ to $190 \mathrm{~nm}$ at a scanning rate of 100 $\mathrm{nm} / \mathrm{min}$. Three successive wavelength scans were taken to average for each sample. 


\subsubsection{Fourier-Transform Infrared Spectroscopy}

Sample aliquots were dried as a thin film and IR spectra were acquired using Bruker (model no: Alpha) in ATR mode (Platinum ATR) at room temperature and averaging 256 scans with $4 \mathrm{~cm}^{-1}$ resolution. Background spectra were subtracted from each sample spectrum.

\subsubsection{Powder X-ray diffraction (PXRD)}

The XRD measurements were performed with a Rigaku (mini flex II, Japan) powder X-ray diffractometer having $\mathrm{Cu} \mathrm{K} \alpha=1.54059 \AA$ radiation. Briefly, assembled peptide nanotubes were bundled with 10 equivalent sodium sulfate. Instant white precipitate was obtained which was collected by centrifugation. White dry powder for X-ray diffraction was made through the lyophilization of the frozen pellet.

For the creation of panel $3 d$, we have used distances experimentally found from powder X-ray diffractions of the lyophilized peptide assemblies. The $\mathrm{H}$-bonding spacing between the antiparallel strands was found to be $4.65 \AA$ and $4.72 \AA$ respectively for Im-KL and Im-OL (Figure 2f, S9). Due to antiparallel registry, the $\mathrm{N}$-terminals facing the solvents is separated by $9.3 \AA$ (4.65x2) and $9.44 \AA(4.72 \times 2)$ respectively. ${ }^{6}$ The laminate distances between the $\beta$ sheets were measured from the peak at 10.62 and $10.52 \AA$ respectively. With the help of these distances, the grids were prepared with the help of standard drawing software.

\subsubsection{Confocal Microscopy}

$1 \mu \mathrm{L}$ Coumarin 343 dye $(3.5 \mathrm{mM})$ was mixed with $10 \mu \mathrm{L}$ of $\mathrm{Im}-\mathrm{KL}(2.5 \mathrm{mM})$ and incubated for $2 \mathrm{~h}$. The solution was then casted on a glass slide and was enclosed with a cover glass. Confocal image was taken at frame of $512 \times 512$, with 12 bit depth with a $100 \mathrm{X}$. Plano Apochromat objective, N.A.1.4, excited by $88 \mathrm{~nm}$ laser line, emission bandwidth of 493-560 $\mathrm{nm}$ in CLSM 710 (ZEISS Axio observer 2.0).

\subsubsection{HFIP Study}

$500 \mu \mathrm{L}$ of $\mathrm{Im}-\mathrm{KL}$ was centrifuged for $15 \mathrm{~min}$ at $10000 \mathrm{rpm}$ at $4^{\circ} \mathrm{C}$ in a $1.5 \mathrm{~mL}$ microcentrifuge tubeto form pellet. After removing the supernatant, $450 \mu \mathrm{L}$ of HFIP was added and the mixture was incubated for $2 \mathrm{~h}$ for the disassembly. HFIP was removed by $\mathrm{N}_{2}$ blowing and dried for 2 $\mathrm{h}$ under vacuum. Afterwards $500 \mu \mathrm{L}$ of water was added to the film of disassembled peptide to make the final concentration of peptide to be $2.5 \mathrm{mM}$. 


\subsubsection{Activity measurement of p-nitrophenyl 4-oxopentanoate (1), and p-nitrophenyl pentanoate (2)}

To check hydrolase activity of peptide assemblies at $\mathrm{pH} 8,0.55 \mu \mathrm{L}$ of substrate $(10 \mathrm{mM}$ acetonitrile stock) was added to a mixture of $44 \mu \mathrm{L}$ of redispersed peptide ( $2.5 \mathrm{mM} \mathrm{pH} 8$ buffer stock) and $65.25 \mu \mathrm{L}$ of $25 \mathrm{mM}$ HEPES buffer $(\mathrm{pH} 8)$. The hydrolytic product $\mathrm{p}$-nitro phenol (NP) absorbs at $400 \mathrm{~nm}$, so reaction rate was determined by monitoring the absorbance at $400 \mathrm{~nm}$ by Biobase UV spectrometer. The extinction coefficient of NP at pH 8 was $16600 \mathrm{M}^{-}$ ${ }^{1} \mathrm{~cm}^{-1}$.

\subsubsection{Activity measurement of 6-formyl napthalene-2-yl acetate (3)}

The activity of peptide assemblies towards 3 was measured as mentioned above. The hydrolysed product 6-hydroxy naphthaldehyde absorbs at $310 \mathrm{~nm}$, and the hydrolysis rate was determined by monitoring absorbance at $310 \mathrm{~nm}$.

\subsubsection{Activity measurement of napthalene-2-yl acetate (4)}

Hydrolysis of $\mathbf{4}$ was monitored by fluorescence spectroscopy using Cary Agilent spectrofluorometer. The hydrolysed product 2-naphthol gives emission band at $356 \mathrm{~nm}$, when it was excited at $330 \mathrm{~nm}$. Fluorescence of 2-naphthol at various concentration was also monitored to construct a standard curve against known concentration. This standard curve allowed us to determine the product concentration.

\subsubsection{Reductive amination of iminium intermediate}

Im-KL peptide and $\mathbf{1}$ was initially mixed in methanol and the reaction mixture was kept for 10 h. Then the reaction mixture was incubated with $\mathrm{NaBH}_{3} \mathrm{CN}$ for next $12 \mathrm{~h}$. After that, the resulting solution was analysed in Bruker ESI-MS.

ESI-MS of Stable amino-Im-KL $\left(\mathrm{C}_{54} \mathrm{H}_{81} \mathrm{~N}_{11} \mathrm{O}_{10}\right):(\mathrm{m} / \mathrm{z})$ calculated $\left[\mathrm{M}+\mathrm{H}^{+}\right]$: 1044.6201 , found 1044.6159 $\left[\mathrm{M}+\mathrm{H}^{+}\right]$, calculated $\left[\mathrm{M}+\mathrm{Na}^{+}\right]:$1066.6168, found 1066.6000

\subsubsection{Determination of molar extinction coefficient of 6-hydroxy 2-naphthaldehyde}

A standard plot was constructed using UV absorbance at $310 \mathrm{~nm}$ for various known concentration of 6-hydroxy 2-naphthaldehyde. Molar extinction coefficient was determined 
according to the equation $A=\varepsilon \mathrm{cl}$. It was found that, Molar extinction coefficient of 6 -hydroxy 2-naphthaldehyde at $\mathrm{pH} 8$ was $12540 \mathrm{M}^{-1} \mathrm{~cm}^{-1}$.

\subsubsection{Epifluorescence microscopy}

$0.5 \mu \mathrm{L}$ of 1 (5 mM stock) was added to a mixture of $10 \mu \mathrm{L}$ redispersed peptide (2.5 mM stock) and $39.5 \mu \mathrm{L}$ buffer (25 mM HEPES, $\mathrm{pH}$ 8). The reaction mixture was then casted on a glass slide and was enclosed with a cover glass. Images were taken at various time interval with IX81, Olympus, Japan, using cool sNp myo, photometrics, and plan fluorite objective with 60 $X$ magnification. At different time intervals, images were recorded in twenty random field of views in triplicate of samples.

\subsubsection{HPLC study}

High performance liquid chromatography (HPLC) was performed in Waters HPLC system (2535 quaternary pump for analytical LC equipped with 2489 UV-Vis detector) Atlantis® T3 C18 $5 \mu \mathrm{m}, 4.6 \times 250 \mathrm{~mm}$ analytical column were used maintaining a flow rate of $1 \mathrm{~mL} / \mathrm{min}$ with a gradient from $30 \%$ to $60 \%$ acetonitrile in water (both solvents contain $0.1 \%$ TFA) with a total run time of $30 \mathrm{~min}$. The formation of hydrolysed product $\mathrm{Ar}-\mathrm{CHO}$ and 2-naphthol was monitored at $310 \mathrm{~nm}$ and $330 \mathrm{~nm}$ respectively. Increase of peak areas were noted and from a standard plot of substrates with known concentration, conversions were calculated. 
Table S1. Activity of various systems for hydrolysis of $\mathbf{1 .}$

\begin{tabular}{|l|l|}
\hline System & Activity $\left(\mu \mathrm{M} \mathbf{~ m i n}^{-1}\right)$ \\
\hline Im-KL & $5.6 \pm 0.5$ \\
\hline Im-RL & $0.49 \pm 0.07$ \\
\hline Im-EL & $0.21 \pm 0.05$ \\
\hline Im-OL & $3.6 \pm 0.6$ \\
\hline HFIP treated Im-KL & $0.11 \pm 0.02$ \\
\hline HFIP treated Im-RL & $0.19 \pm 0.06$ \\
\hline Ac-KL+ Imdazole acetic acid & $0.40 \pm 0.09$ \\
\hline
\end{tabular}

Table S2. Summary of kinetic parameters for hydrolysis for the different substrates. Varying concentration of substrates and $300 \mu \mathrm{M}$ peptides.

\begin{tabular}{|c|c|c|c|c|}
\hline Peptide & Substrate & $k_{\text {cat }}\left(\min ^{-1}\right)$ & $\mathrm{K}_{\mathrm{m}}(\mathrm{M})$ & $\begin{array}{l}\text { Catalytic } \\
\text { efficiency } \\
\left(k_{\mathrm{cat}} / \mathrm{K}_{\mathrm{m}}\right) \\
\left(\mathbf{M}^{-1} \mathrm{sec}^{-1}\right)\end{array}$ \\
\hline Im-KL & & $0.09 \pm 0.02$ & $7.4 \pm 2 \times 10^{-4}$ & $2.1 \pm 0.3$ \\
\hline Im-RL & & $0.07 \pm 0.01$ & $2.4 \pm 0.5 \times 10^{-3}$ & $0.48 \pm 0.09$ \\
\hline Im-KL & & $0.07 \pm 0.02$ & $3.2 \pm 0.7 \times 10^{-4}$ & $3.6 \pm 0.7$ \\
\hline Im-RL & & $0.03 \pm 0.01$ & $3.0 \pm 0.6 \times 10^{-4}$ & $1.8 \pm 0.3$ \\
\hline
\end{tabular}




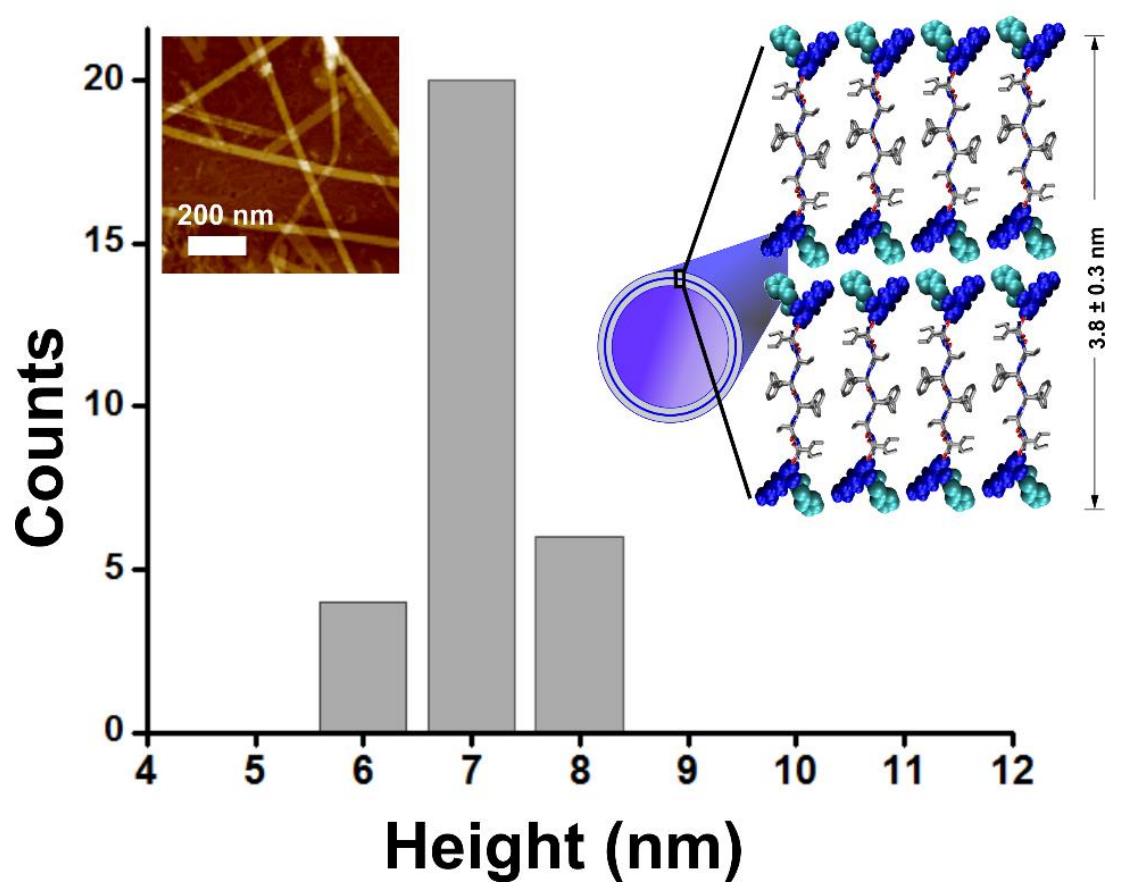

Figure S1. Histogram of height of nanostructures measured from multiple AFM images (average $=7.6 \pm 0.7 \mathrm{~nm}$ ). Inset showing AFM image of $\mathrm{Im}-\mathrm{KL}$ peptide nanotubes.

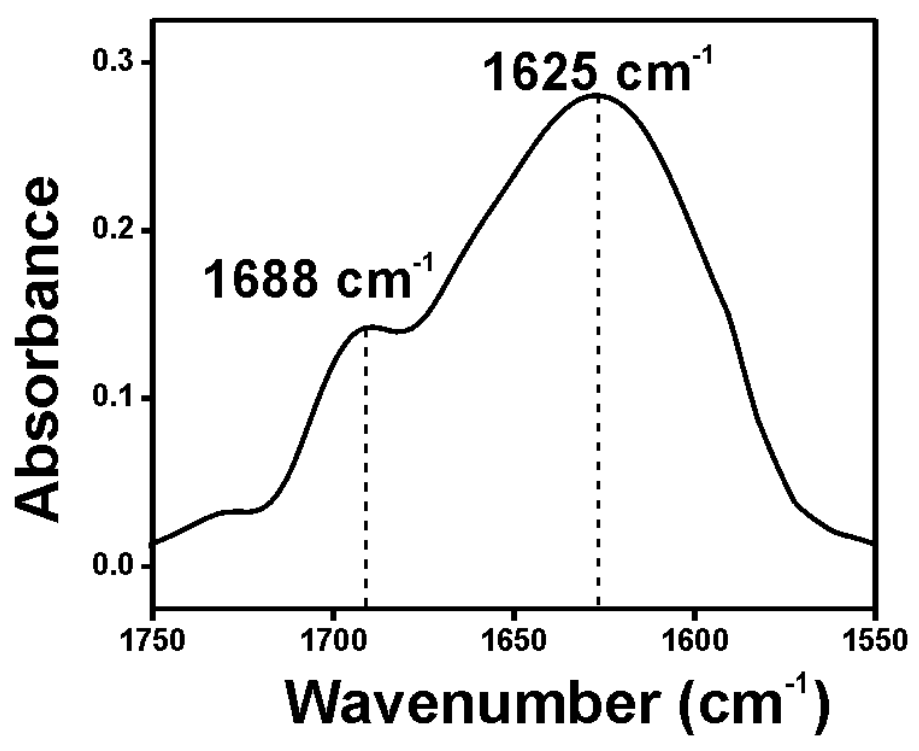

Figure S2. FTIR spectra of Im-KL nanotubes. 


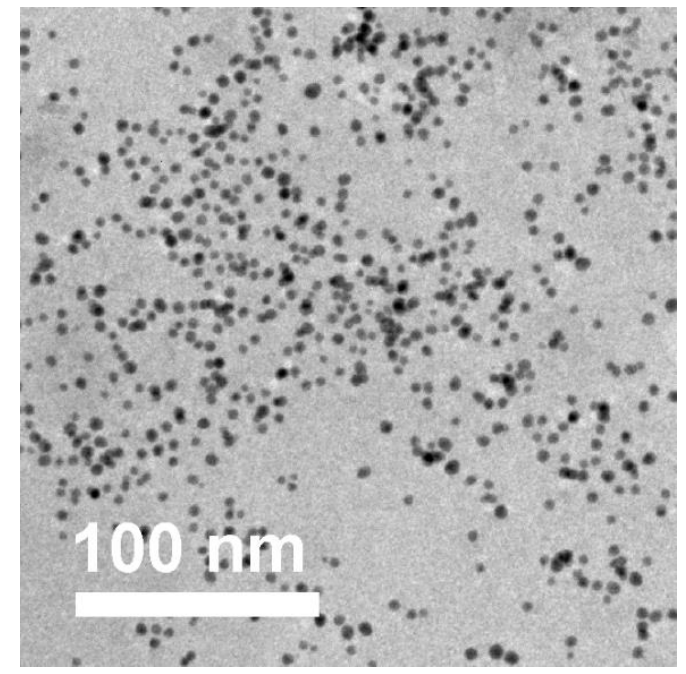

Figure S3. TEM image of negatively-charged citrate capped gold nanoparticles.
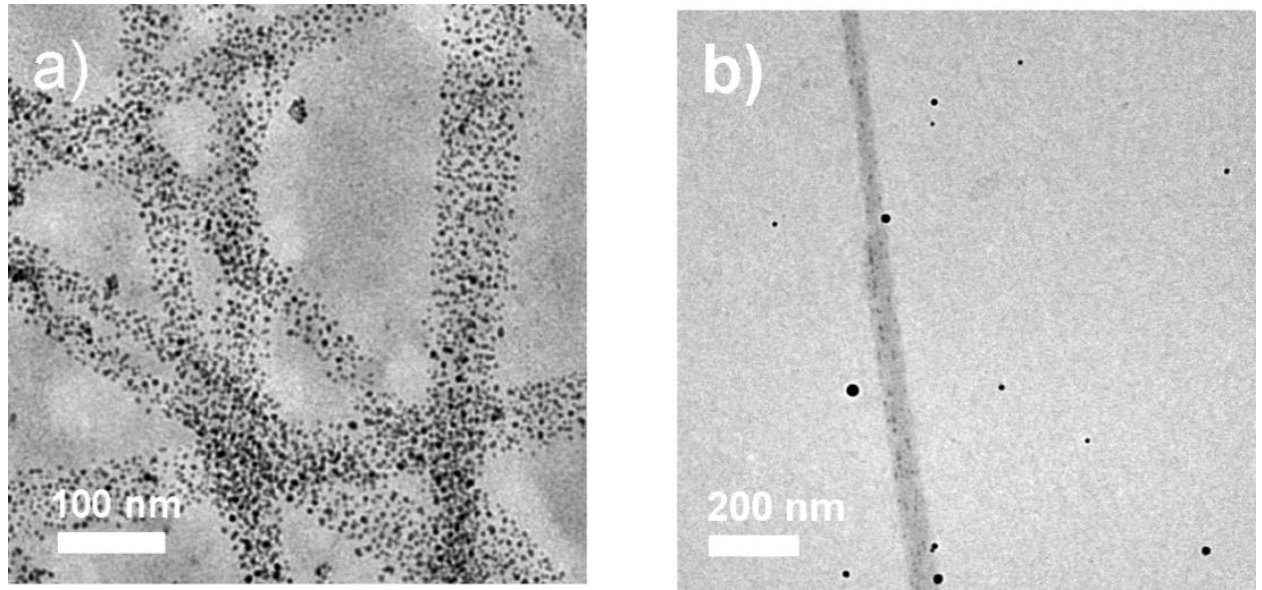

Figure S4. a) Negatively charged gold nanoparticle bound Im-KL b) Positively charged gold nanoparticles incubated with $\mathbf{I m - K L}$ nanotubes. 


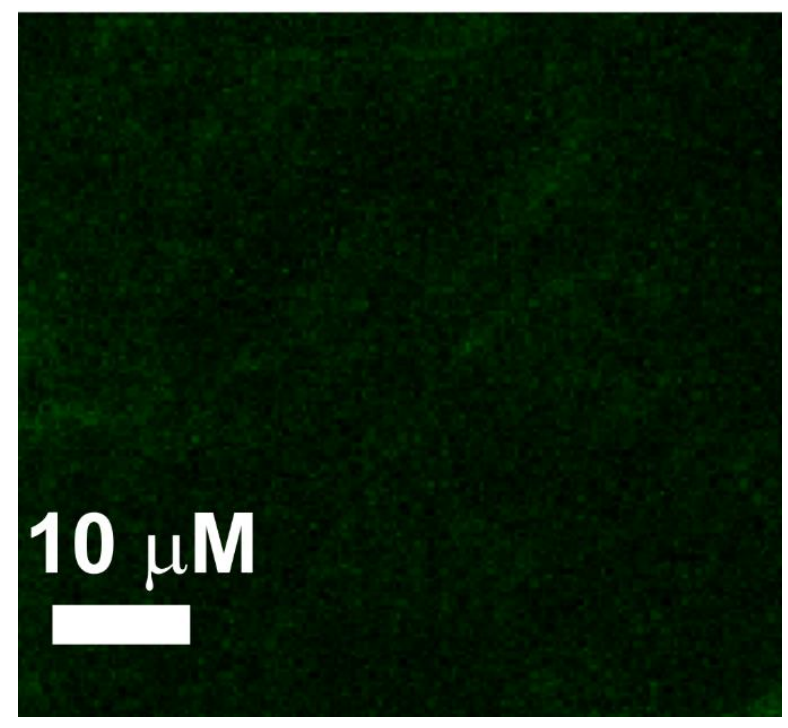

Figure S5. Confocal laser scanning microscopy images of coumarin 343 dye without Im-KL tubes.

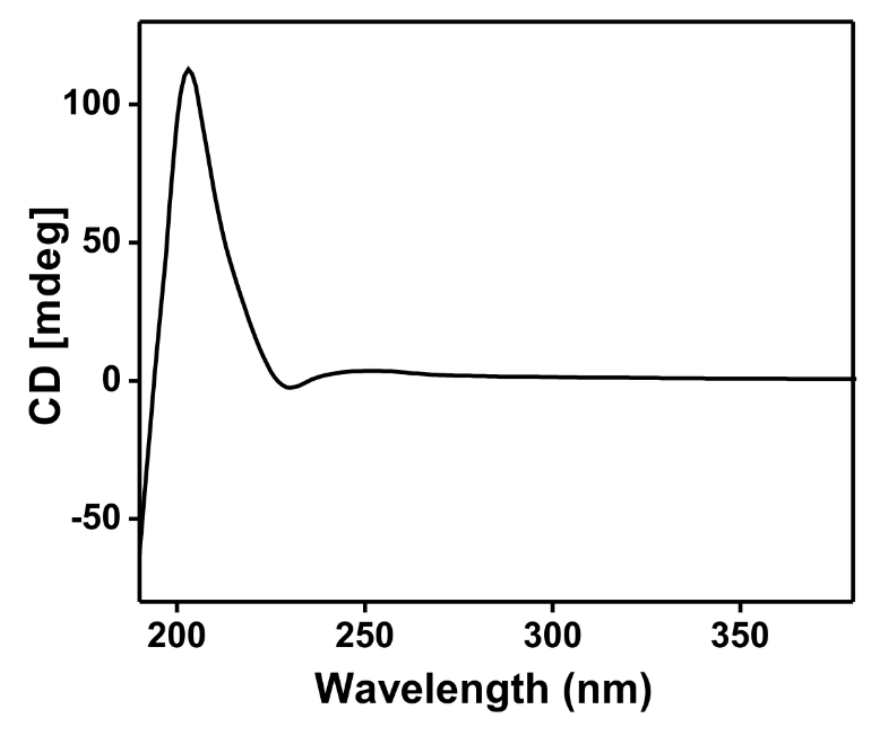

Figure S6. CD spectra Im-RL. 

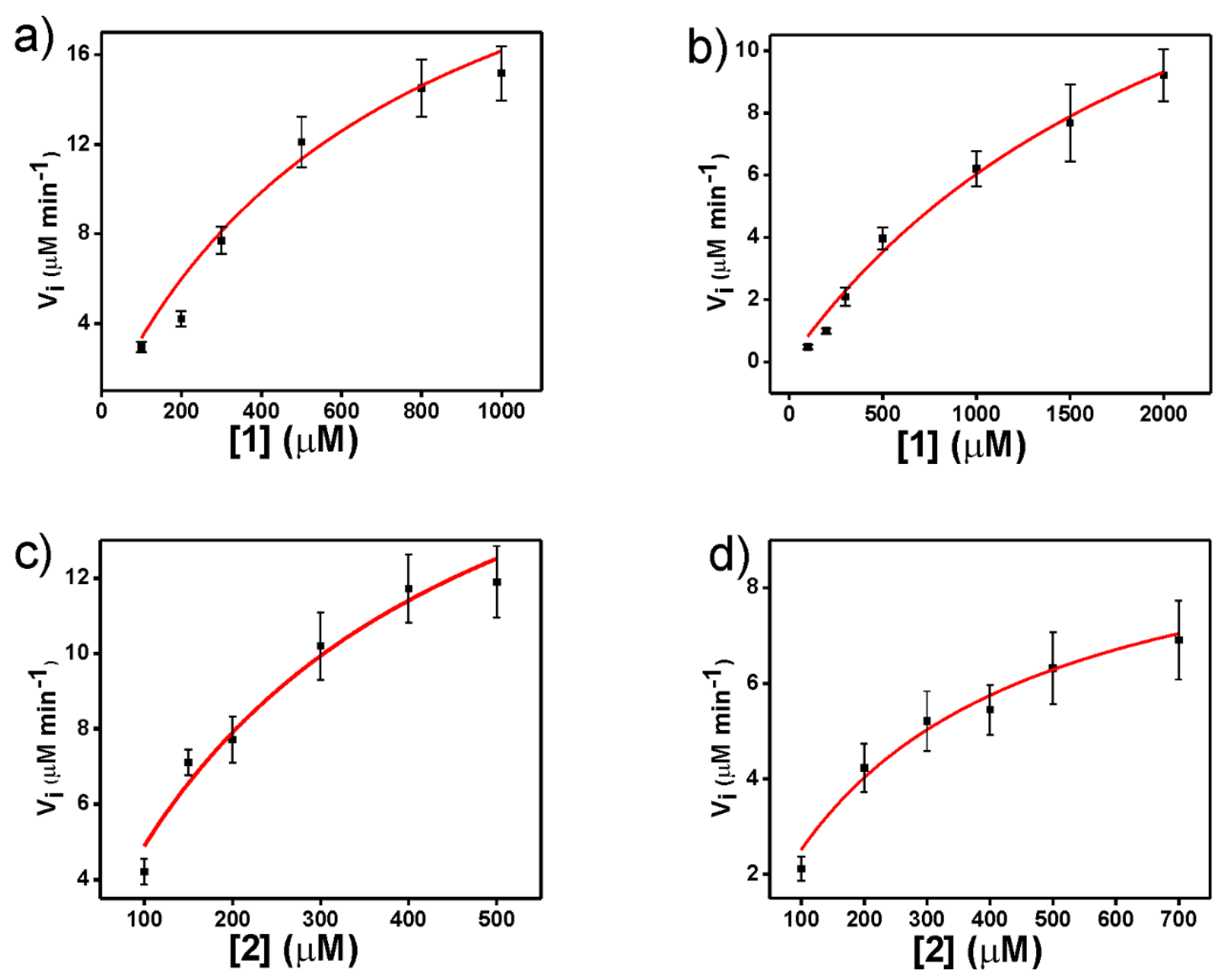

Figure S7. Representative Michaelis - Menten plots for a) Im-KL and b) Im-RL for substrate $\mathbf{1}, \mathrm{c}) \mathrm{Im}-\mathrm{KL}$ and d) Im-RL for substrate $\mathbf{2}$.

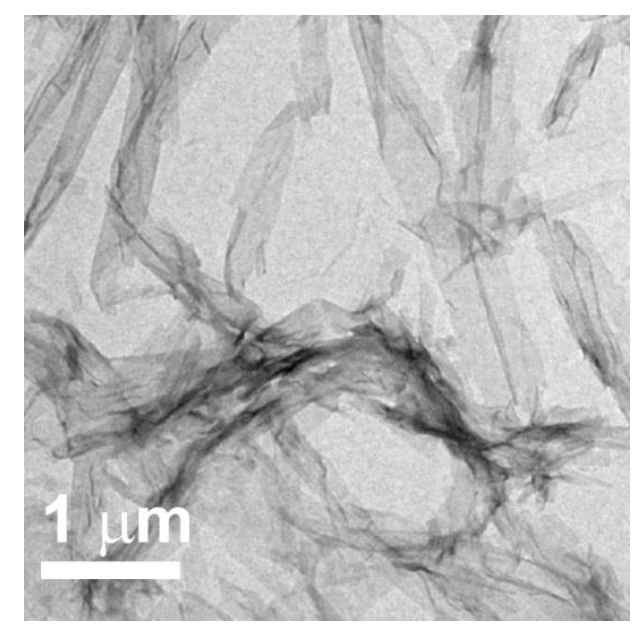

Figure S8.TEM image of Im-EL 


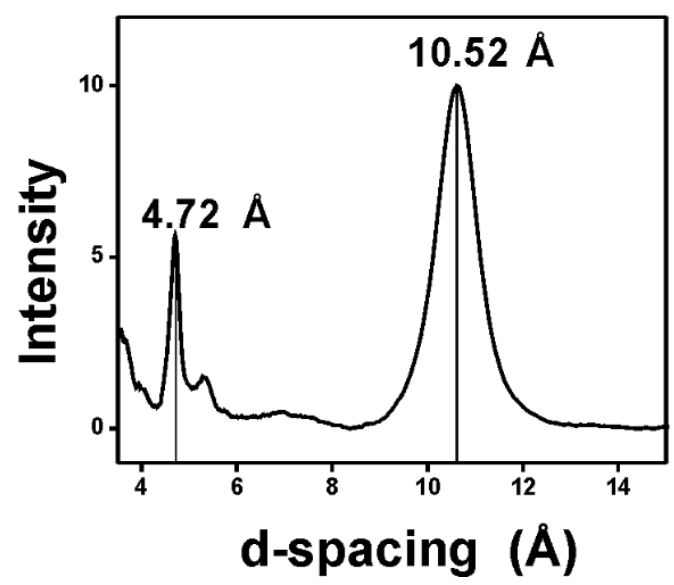

Figure S9. X ray powder diffraction showing reflections at d-spacing of $4.72 \AA$ and $10.52 \AA$ for Im-OL.

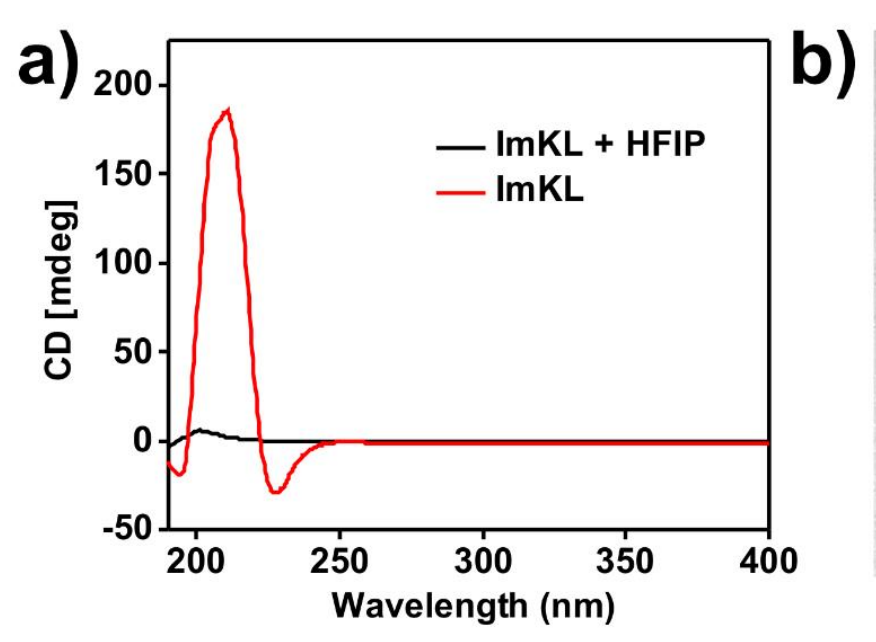

Figure S10. CD spectra of a) Im-KL and HFIP treated Im-KL and b) corresponding TEM image of disassembled nanotubes. 


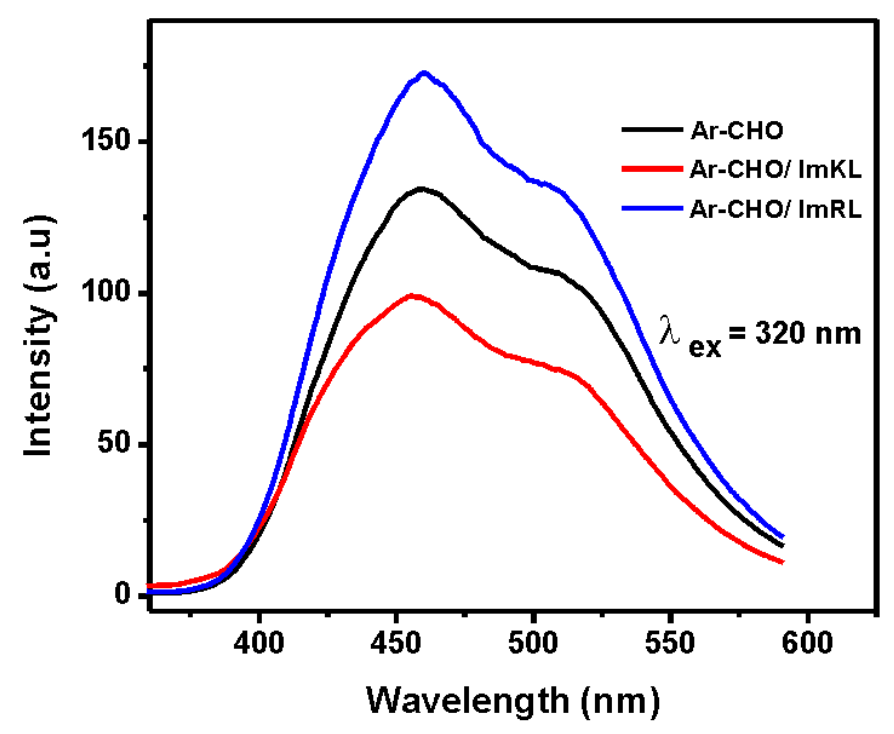

Figure S11. Fluorescence spectra indicating covalent imine formation between Ar-CHO and Im-KL and non-covalent interaction of Ar-CHO and Im-RL.

a)

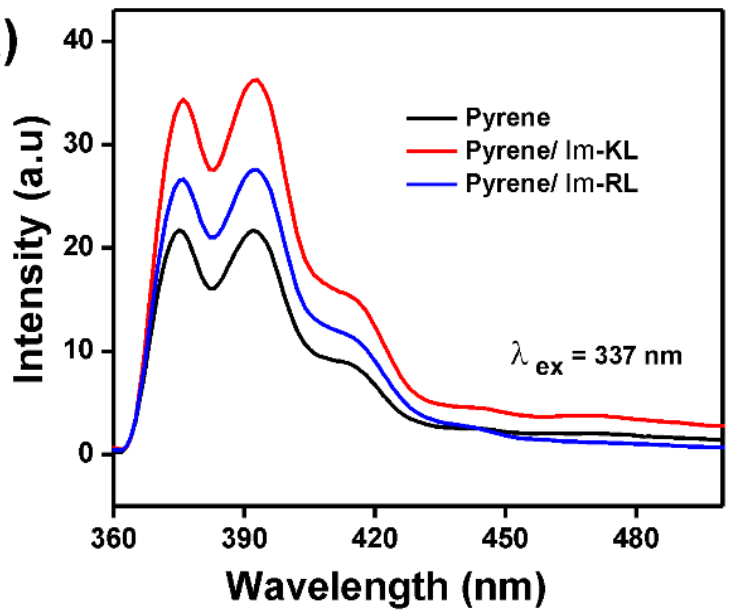

b)

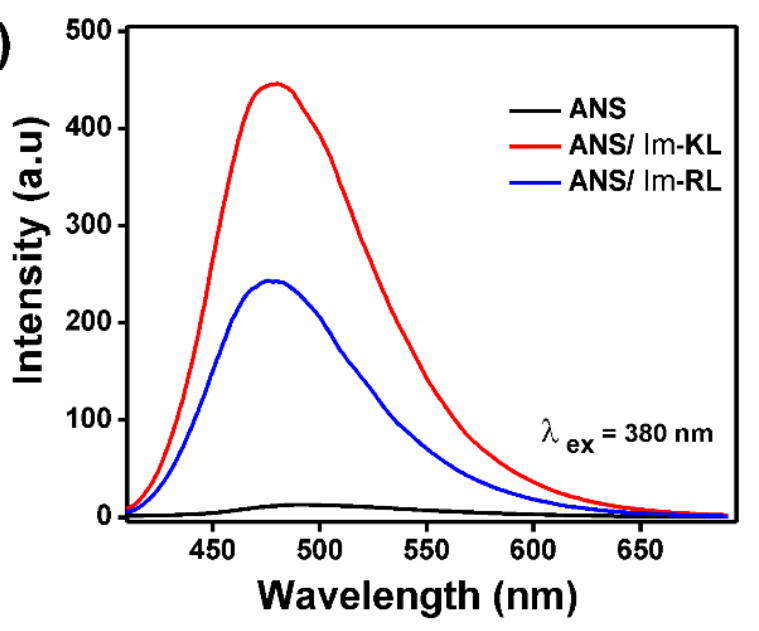

Figure S12. Fluorescence spectra confirming non-covalent binding of a) pyrene and b) ANS to both Im-KL and Im-RL assemblies. 


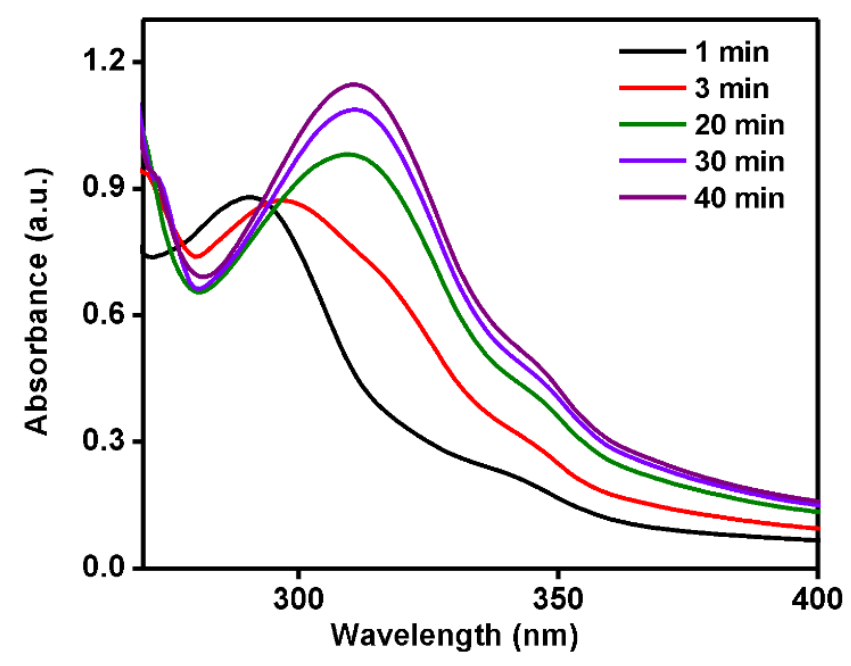

Figure S13. Time course generation of UV spectra of 6-Hydroxy 2-naphthaldehyde (ArCHO) in presence of Im-KL.

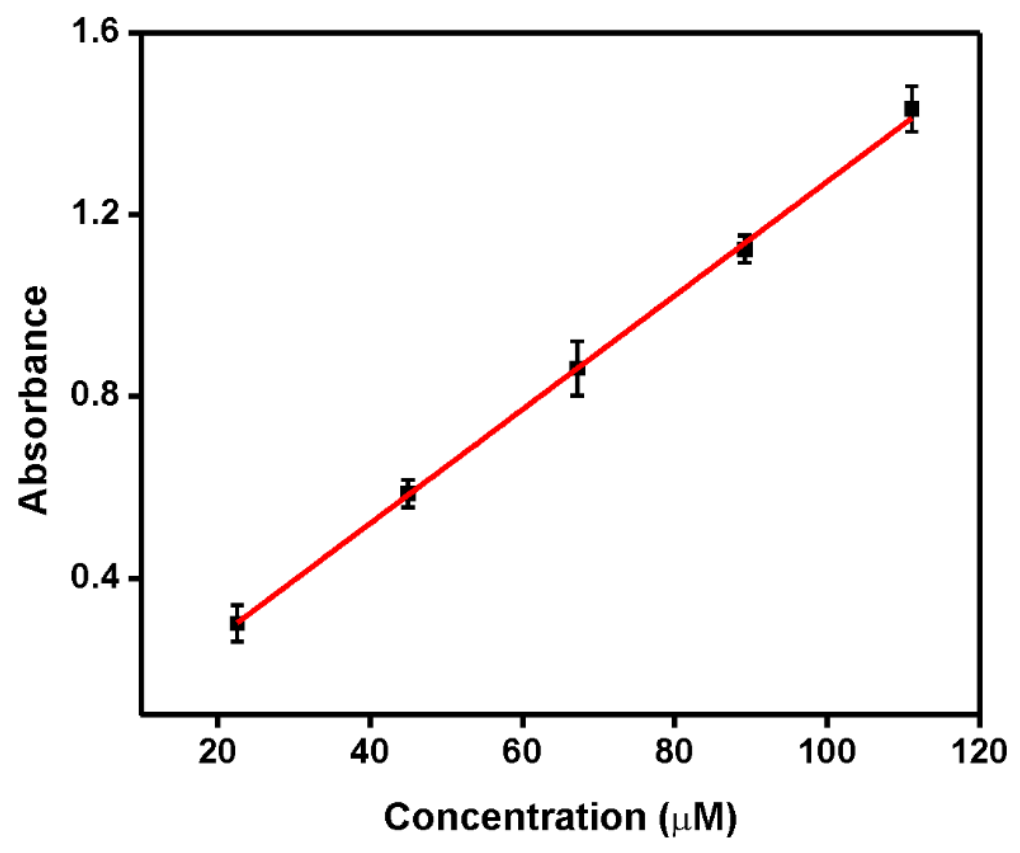

Figure S14. Standard plot of absorbance against known concentration of 6-hydroxy 2naphthaldehyde (Ar-CHO). 


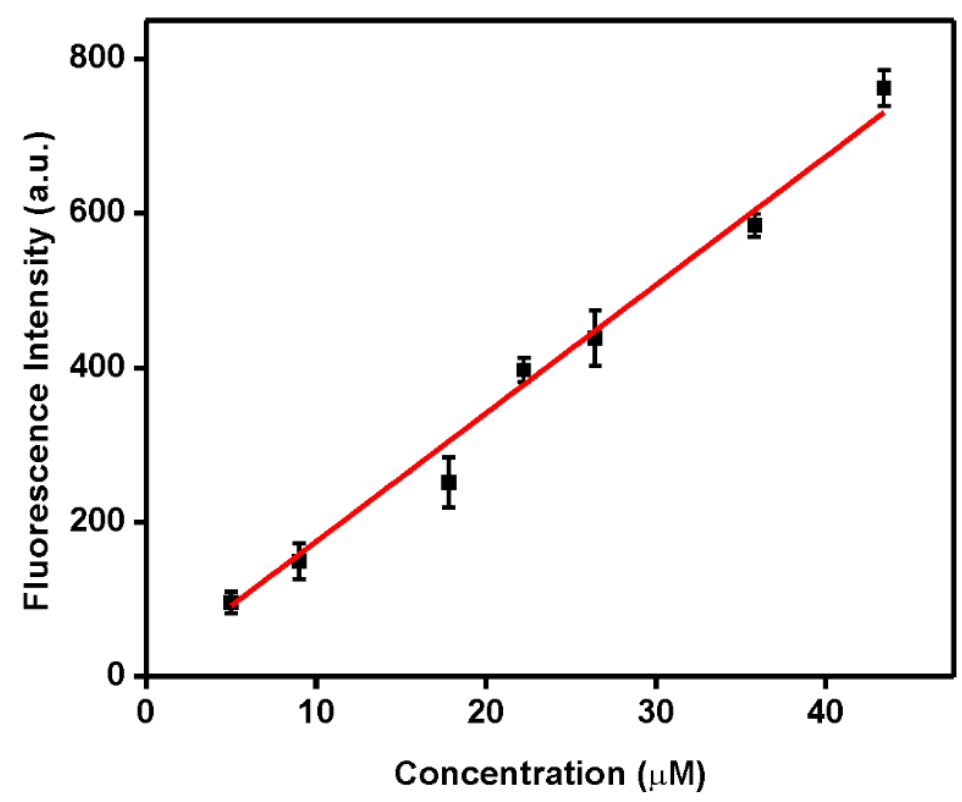

Figure S15. Standard plot of fluorescence intensity against known concentration of 2Naphthol.
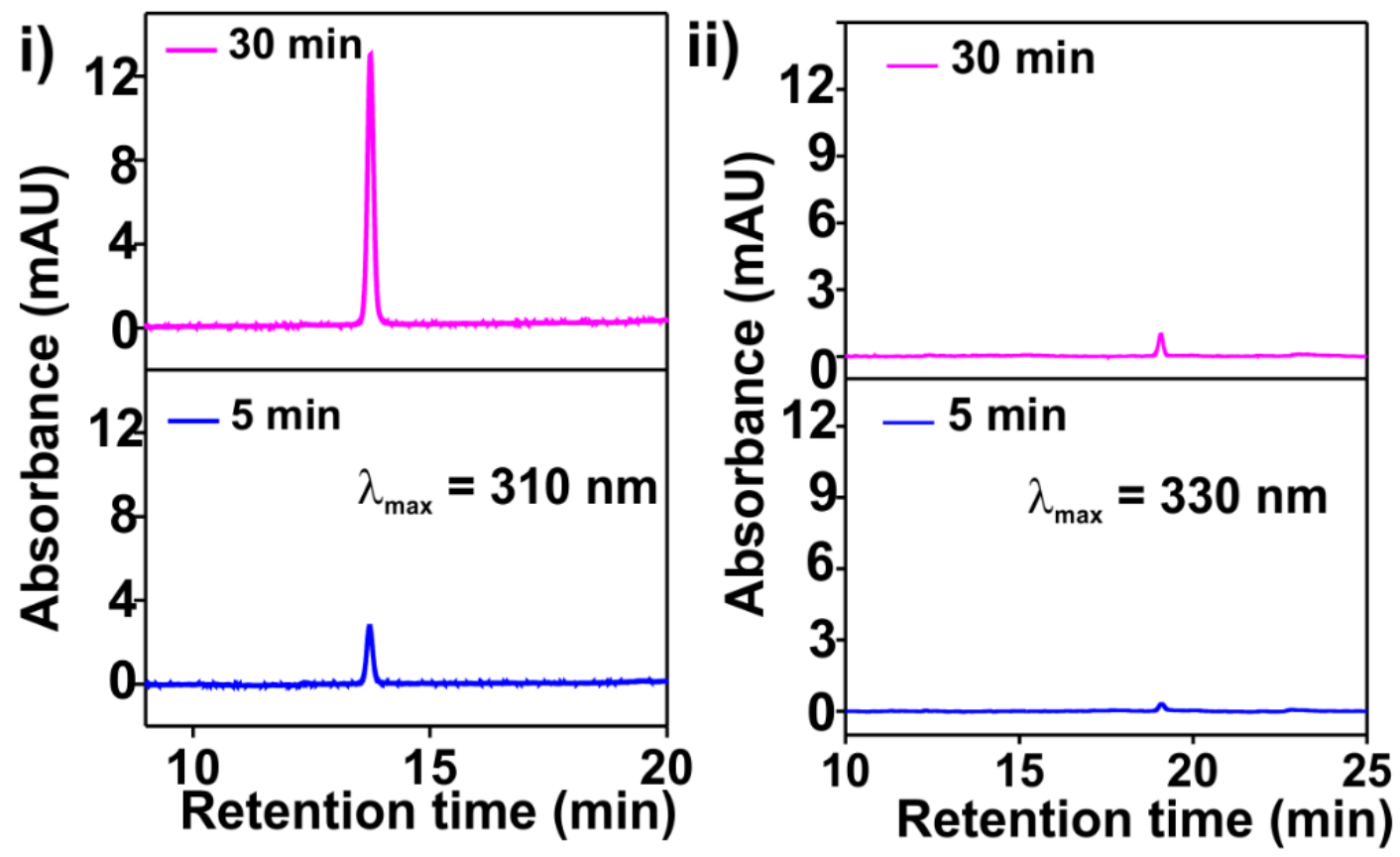

Figure S16. b) Time-dependent HPLC chromatogram for formation of hydrolyzed product of i) substrate 3 and ii) substrate 4. 

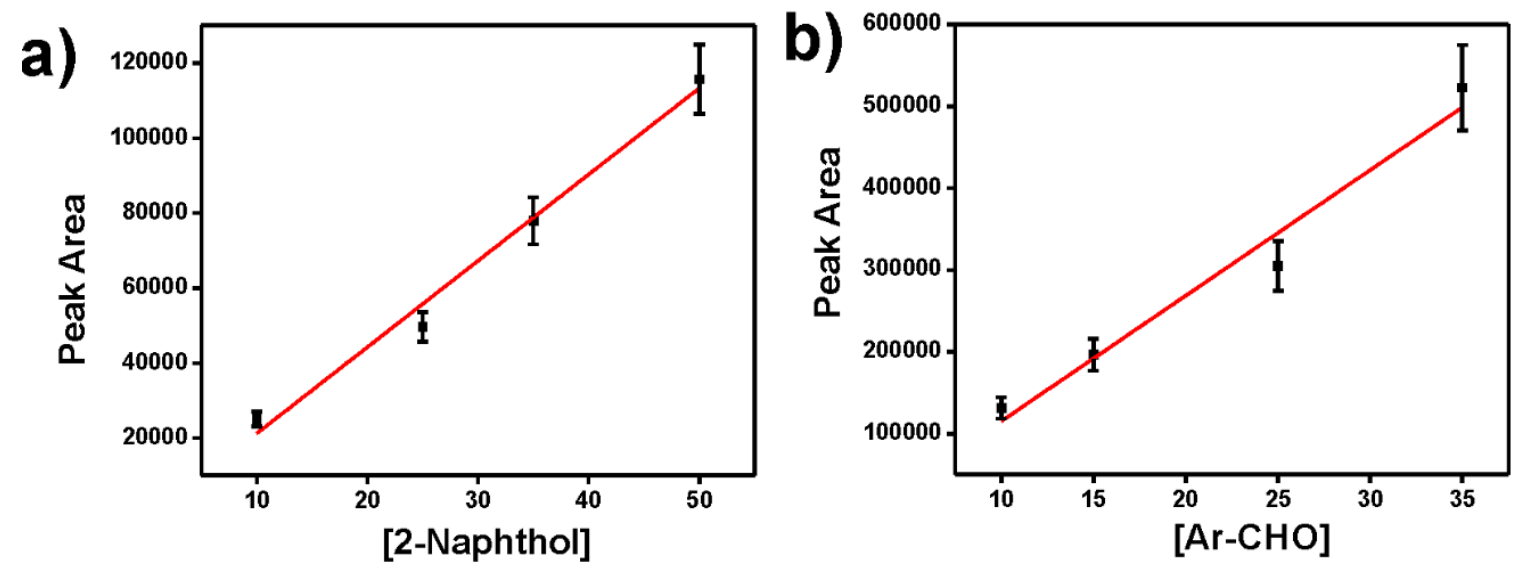

Figure S17. Standard curve of product a) 2-Naphthol b) 6-Hydroxy Naphthaldehyde (ArCHO) from HPLC.

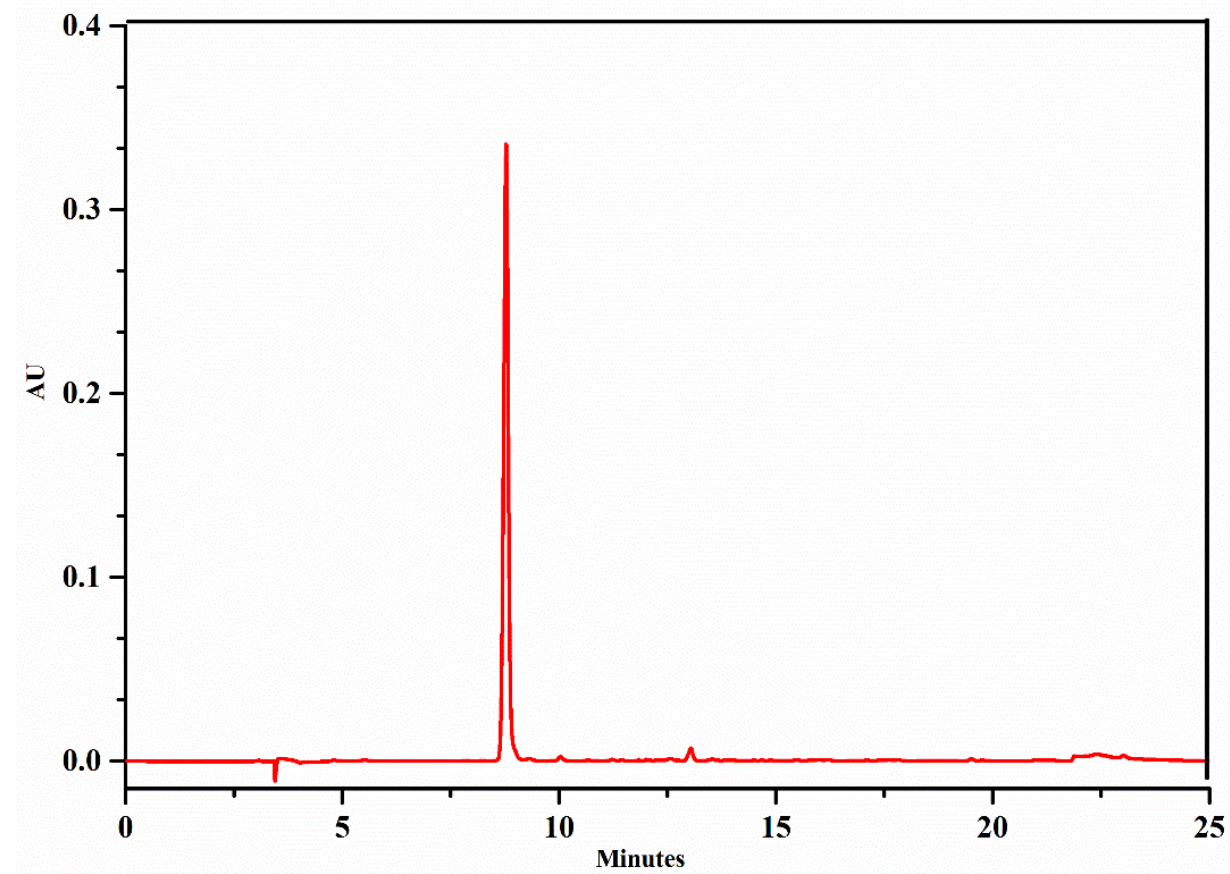

Figure S18. HPLC chromatogram of purified peptide Im-KL (C18 Column, linear gradient from 30 to $60 \%$ in MeCN in $30 \mathrm{~min}$ ). 


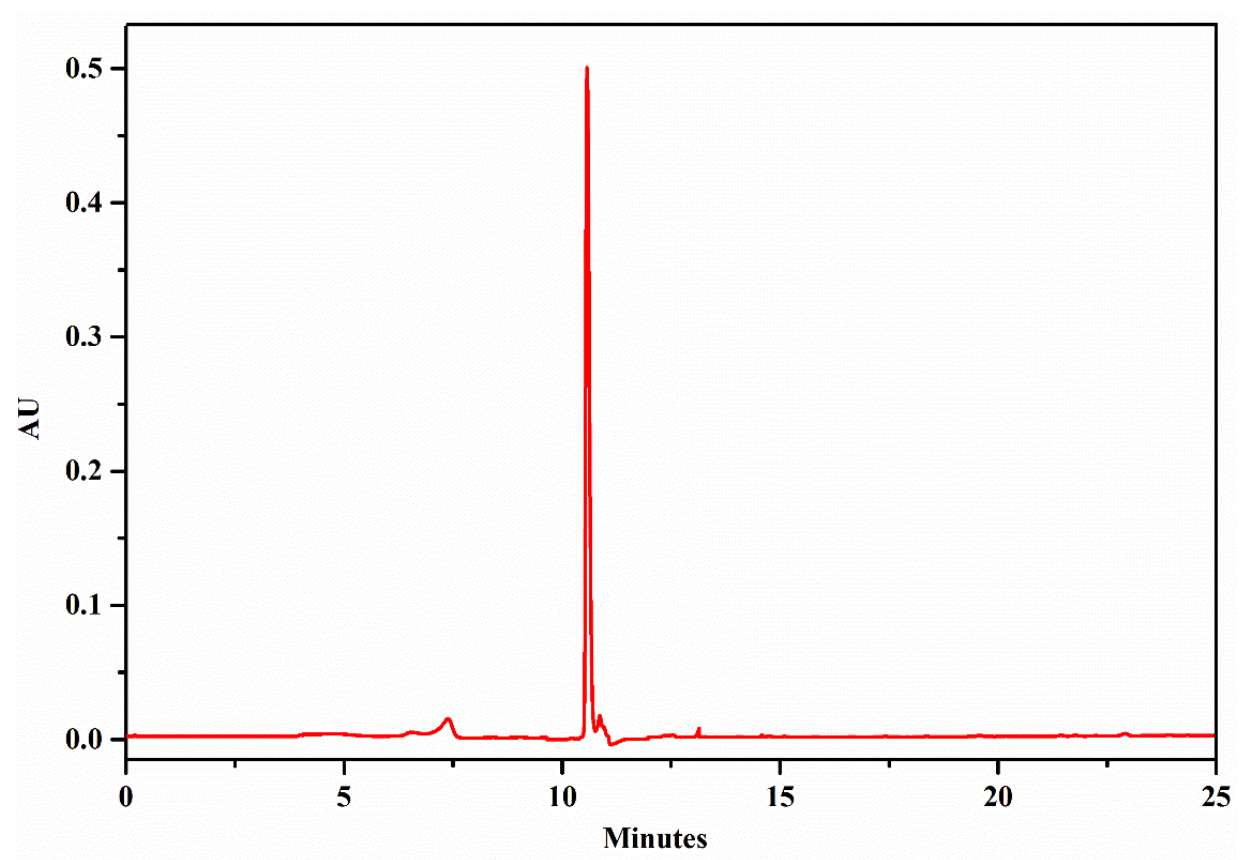

Figure S19. HPLC chromatogram of purified peptide Im-RL (C18 Column, linear gradient from 30 to $60 \%$ in MeCN in 30 min).

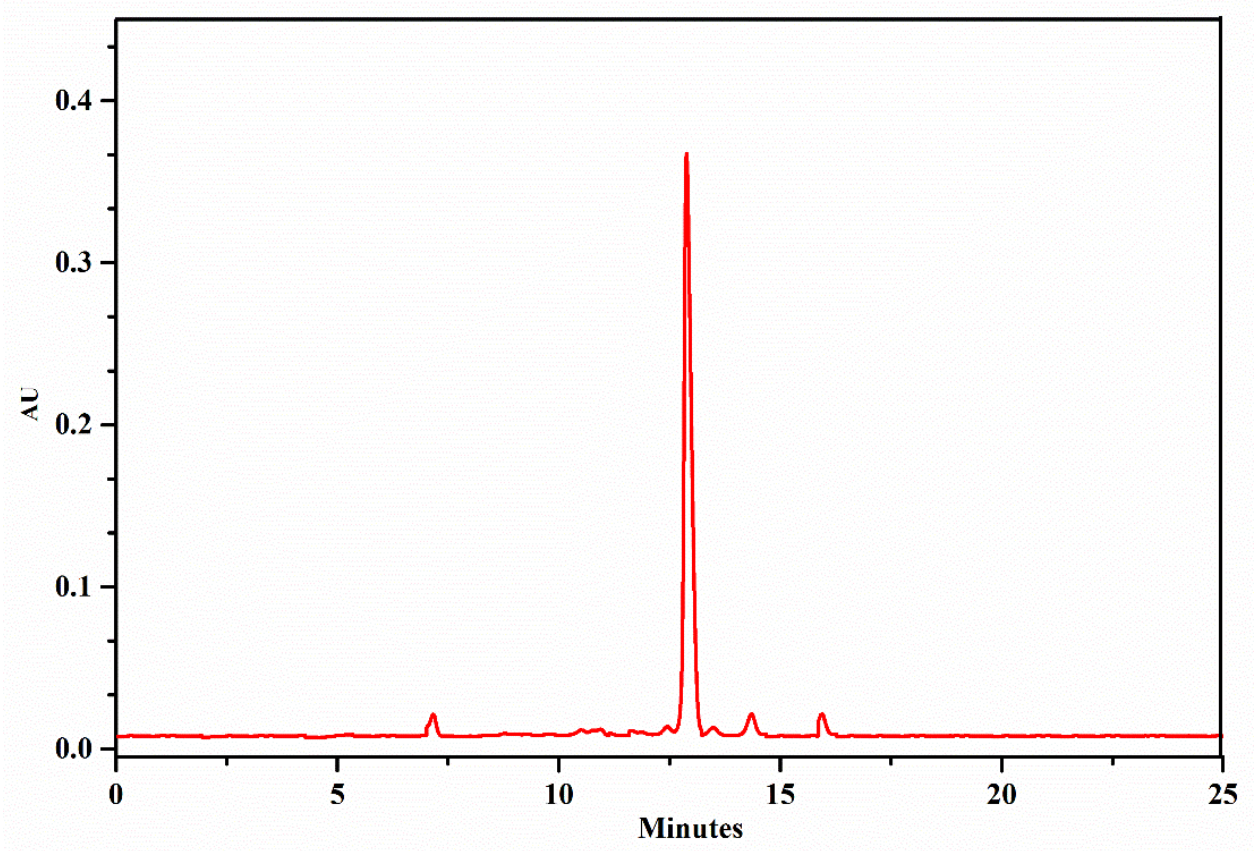

Figure S20. HPLC chromatogram of purified peptide Im-EL (C18 Column, linear gradient from 30 to $60 \%$ in $\mathrm{MeCN}$ in $30 \mathrm{~min})$. 


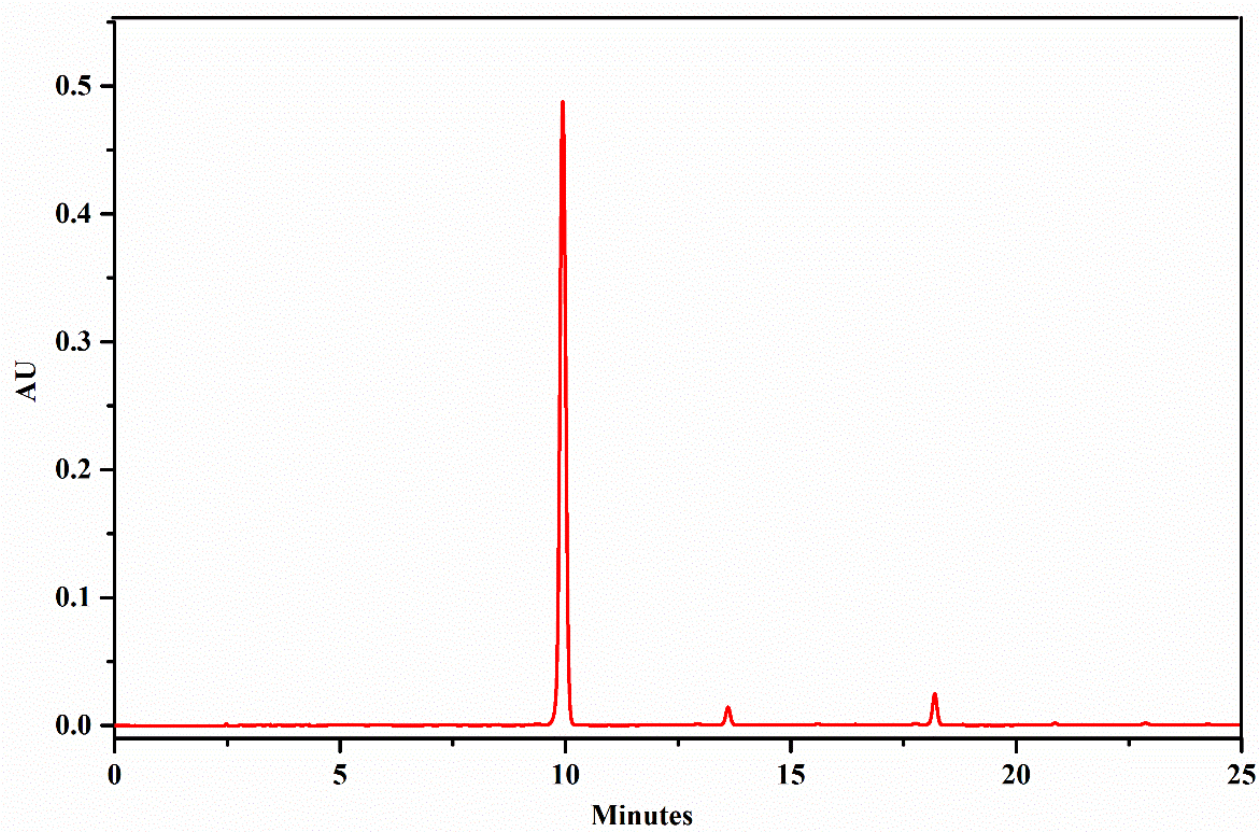

Figure S21. HPLC chromatogram of purified peptide Im-OL (C18 Column, linear gradient from 30 to $60 \%$ in MeCN in $30 \mathrm{~min})$.

Reference:

1. Gärtner, D.; Welther, A.; Rad, B. R.; Wolf, R.; von Wangelin, A. J. Heteroatom-Free Arene-Cobalt and Arene-Iron Catalysts for Hydrogenations. Angew. Chem., Int. Ed. 2014, 53, 3722-3726.

2. Álvarez-Calero, J. M.; Jorge, Z. D.; Massane; G. M. TiCl4/Et3N-Mediated Condensation of Acetate and Formate Esters: Direct Access to $\beta$-Alkoxy- and $\beta$ Aryloxyacrylates. Org. Lett. 2016, 18, 6344-6347.

3. Li, S.; Sidorov, A. N.; Mehta, A. K.; Bisignano, A. J.; Das, D.; Childers, W. S.; Schuler, E.; Jiang, Z.; Orlando, T. M.; Berland, K.; Lynn, D. G. Neurofibrillar Tangle 
Surrogates: Histone H1 Binding to Patterned Phosphotyrosine Peptide Nanotubes. Biochemistry 2014, 53, 4225-4227.

4. Kapil, N.; Singh, A.; Das, D. Cross- $\beta$ Amyloid Nanohybrids Loaded With Cytochrome C Exhibit Superactivity in Organic Solvents. Angew. Chem. Int. Ed. 2015, 54, 64926495.

5. Kapil, N.; Singh, A.; Singh, M.; Das, D. Efficient MoS2 Exfoliation by Cross- $\beta$-Amyloid Nanotubes for Multistimuli-Responsive and Biodegradable Aqueous Dispersions. Angew. Chem. Int. Ed. 2016, 55, 7772-7776.

6. Childers, W. S.; Mehta, A. K.; Lu, K.; Lynn, D. G. Templating Molecular Arrays in Amyloid's Cross- $\beta$ Grooves. J. Am. Chem. Soc. 2009, 131, 10165-10172. 